Published in: Tijdschrift voor Genderstudies 19:3 (2016) 373-387

\title{
Monuments for the common (wo)man: diary archives in Europe
}

Interview with Monica Soeting, co-founder of the Dutch Diary Archive

\section{Marijke Huisman}

\section{Abstract}

Life writing documents are not difficult to find; they are part of any archive's inventory. Nonetheless, a number of European countries have recently witnessed the rise of a new, genre-based type of archive: the diary archive. The Archivio Diaristico Nazionale (1984) in Italy was the first of this kind, and more were to follow, like the Association pour l'autobiographie et le patrimoine autobiographique in France (APA, 1992), the Deutsches Tagebucharchiv (1998), and the Nederlands Dagboekarchief (Dutch Diary Archive, 2009). How and why did these archives come into being, what are their characteristic features, and what is the relevance of these form-based collections to gender studies? I asked Monica Soeting, co-founder of the Dutch Diary Archive, and contextualized the work of the Dutch in the broader field of European diary archives.

Keywords - diaries - archives - public history - interview - Europe

The story of the Dutch Diary Archive starts in 2009, when communication advisor Mirjam Nieboer inherited a set of 37 diaries written by her husband's grandfather. Looking for an archive where she could store these documents, Nieboer found out that the diaries were not compatible with the selection policy of archival institutions in the Netherlands (Huitema, p. 25). Some archives were only interested in documents from a specific time period, while others specialized in certain social groups, and virtually all archives - thematic or national, regional, municipal - faced the practical problem of lack of funding and therefore not enough space to enlarge their collections. When Nieboer met Monica Soeting, independent journalist, biographer and chief editor of the European Journal of Life Writing, both women considered the possibility to establish a new archive and travelled to the Deutches Tagebucharchiv in Emmendingen for inspiration. Upon their return, they founded the Dutch Diary Archive. At first the archive consisted of just one collection, the grandfather's diaries, but media attention stimulated people to send in a substantial number of diaries, all of which were stored in Nieboer's attic. As the collection grew, adequate storage space had to be found. A temporary solution was provided by the library of VU University in Amsterdam, but in 2013 the collection acquired permanent residence in The Meertens Insitute, a former folklorist research centre that now specializes in Dutch language and (everyday) culture, also in Amsterdam. 'Diaries and other life writing documents perfectly fit in their mission and research projects', says Soeting.

Since the start of the Dutch Diary Archive ever more donations have been brought in: 'Some people bring the diaries of their deceased relatives, others bring their own diaries. We receive diaries from thrift shops and from notaries; they have been written by old and young alike. Most people bring the diaries for safe keeping: they hate the idea that the diaries might be thrown away by a careless family member, or just get lost. Thrift shop owners send diaries 
because they don't like to throw away personal documents like diaries.' In April 2016 Soeting estimated the number of diary collections (which may comprise all sorts of life writing documents) a little over one hundred, 'but the number of documents is several hundreds - we will know the exact number as soon as the database is fully operative.' What is clear, though, is the time span: 'Our eldest collection stems from around 1840; the youngest is a diary finished around one month ago.' As to the representation of Dutch society, Soeting tells that 'all sorts of people bring diaries to the archive. They greatly differ in age, class and gender, but alas not in race - most of the people, though not all, are white. But we think the collection is more or less representative for the Dutch population since the second half of the nineteenth century, although diaries of immigrants are under-represented. It would be great if we would receive more of these diaries. The Amsterdam public library will organise an exhibition in the spring of 2017, at which we will also be able to inform the public abour our collection. I do hope we will be able to reach a wider public through the exhibition and our talks. For research a more representative collection would be ideal, and we aim to make our collection as diverse and therefore representative as possible in order to really be a diary archive for the 'common' people, that is a diary archive for everybody Dutch or living in the Netherlands.'

Given the ambitions, it is noteworthy that the Dutch Diary Archive has no paid staff. The four board members, Susanne Neugebauer, Marjet van Elten, Jaap van Zaane and GeertJan Meijerhof, volunteer, as well as the 37 women and 8 men who read and index the documents to make them accessible through the Meertens Institute's collection catalogue. All other work is handled by four staff members, of whom only heritage specialist Nina Wijsbek has a one-day-per-week appointment at the Meertens Insititue. The other three, Monica Soeting, Mirjam Nieboer and Bertie van der Meij, volunteer. Personal relations bind the team of diary enthusiasts together. Soeting: 'Mirjam contacted me, because she knew I was interested in life writing; we asked my friend Bertie van der Meij to join us because of her computer skills, and because she is a professional translator and graphic artist - she designs the booklets we publish each year. Nina Wijsbek, another friend, joined us as she is a historian interested in cultural heritage and was unemployed at the time. The president of the board is an archivist, and a friend, two members of the board are friends of Mirjam, and one is the notary who helped us to formalise the Dutch Diary Archive as a foundation.'

\section{History from below?}

The founding history of the Dutch Diary Archive reflects a number of themes that recur in the histories of other European diary archives. In the first place, there are experiences or feelings of exclusion of common people's documents from mainstream archives. 'A lot of people, if not most, who donate their diaries to the archive, are apologetic,' says Soeting. 'They tell us the diaries are not really interesting, because the entries are not about specific "official” historical events, like the Second World War or the Dutch military actions in Indonesia in the 1940s. There are of course gender aspects to this: diaries of "housewives" are usually thought to be especially uninteresting.' Based in an institute with a strong research tradition in folklore and everyday culture, the Dutch Diary Archive does find such texts as interesting as all other diaries. Common people's documents enhance 'our knowledge of the daily lives of common people, both in the past and the present', according to the Dutch Diary Archive's website (NDA). In a similar vein, the Deutsches Tagebucharchiv-website qualifies 'autobiographische 
Zeugnisse' as 'wichtige Quellen für die Geschichts- und Kulturforschung, vor allem für die Erforschung der Alltags- und Mentalitätsgeschichte’ (DT, Über uns). Women are definitely part of this history, as shown by the fact that women's texts add up to 40 percent of the German collection - which consists of over 15,000 documents. In the list of author's most common job profiles 'housewives' even rank in third place - behind the mixed-gender categories 'teachers' and 'Angestellten' (white collar workers) (DT, Fakten und Zahlen).

While the Dutch and German diary archives formulate their mission in terms of stimulating professional historical research into everyday lifes of common people $(\mathrm{m} / \mathrm{f})$, a second theme in the history of these institutions is that they came into being as brainchilds of women and men without formal connections to the archival or historical profession. Frauke von Troschke, who founded the Deutsches Tagebucharchiv in 1998, was a former president of the Deutscher Kinderschutzbund and Stadträtin in Emmendingen (Walser). She was, in turn, inspired by the Archivio Diaristico Nazionale (1984), initiated by the Italian journalist and writer Saverio Tutino. In this respect, the Association pour l'autobiographie et le patrimoine autobiographique (1992) is the exception. The French association was co-founded by Philippe Lejeune, then professor at the Université de Paris-Est Créteil Val de Marne and world-famous theorist of autobiography and diary. ${ }^{1}$ With regard to the geographical situation, on the other hand, the Dutch Diary Archive is the exception. This is the only institute located in a national capital. The others are situated at the margins of the nations they represent. The French collection is based at the public library in Ambérieu-en-Bugey, near Lyon, while the German archive is situated in the provincial town of Emmendingen, and the Italian archive in the Tuscan town Pieve Sante Stefano, in the Appenine mountains.

Positioned at the margins of the historical infrastructure in their respective countries, diary archives illustrate the vexed relationship between personal documents and the historical discipline. From the early nineteenth century, when the literary and pedagogical practice of writing history was transformed into an academic discipline, professional historians have echoed the principle formulated by Leopold von Ranke (1795-1886): 'bloß zeigen, wie es eigentlich gewesen' (Von Ranke, vii). In order to reconstruct the past as it was, Von Ranke and his contemporaries still used a wide range of historical sources, including personal documents like memoirs, diaries and letters. Over time, however, autobiographical texts were deemed increasingly incompatible with the professional historian's quest for what actually happened in the past (Dekker; Popkin; Huisman, 2011, 2015). First-person narratives were perceived as subjective and more or less fictional, hence not helpful to the historian's truthfinding goals. In the course of the twentieth century, such narratives became even pointless. Once the historical discipline grew closer to the positivist branches of the social sciences, academic fashion drove historians into explanatory (instead of descriptive and narrative) research on long term structural developments in the socio-economic sphere, such as demographic patterns. In this a conception of 'history', the long-standing historiographical genre of biography fell from academic grace and the single human agent, including his - let alone: her - life narrative, was simply redundant.

In the meantime, and mainly outside the academic scene, life writing served as a means to document and write all sorts of alternative or counter-histories. The women's movement of the first feminist wave, for instance, is famous for its output of (auto)biographical writings. Lives of heroic role models filled large numbers of collective 
women's biographies, while pioneering feminists - like the suffragists Elizabeth Cady Stanton, Emmeline Pankhurst and the Dutch Aletta Jacobs - published their autobiographies in order to record (and frame) the movement's history (Booth; Bosch, 2005, p. 24-25). Another case in point is the American Slave Narrative-project (1935-1938), one of the largest public history projects ever undertaken (Yetman; Hirsch). Initiated by African American historian-activist Lawrence D. Reddick, and funded through the federal government's New Deal-programme, unemployed journalists, researchers and other writing professionals travelled the South to interview over 2,000 former slaves and document their memories in order to pluralize national history and identity. Based on these slave narratives folklorist Benjamin Botkin wrote Lay my burden down. A folk history of slavery (1945), in which he explicitly posed 'that history must study the inarticulate many as well as the articulate few' (xxxix).

Demands for an inclusive historiography in terms of class, race and gender increased in the 1960's and 70's, when new social movements propelled 'history from below' and the German variant of Alltagsgeschichte. Less focused on formal working-class institutions like unions, social historians grew interested in the lives, experiences and mentalities of 'common people'. In order to write such (micro)histories, first-person narratives were rediscovered as historical sources. This historiographical tide expressed itself in energetic projects to create (through oral history), find and disseminate life writing documents. In the United States, for instance, the interwar slave narratives were lifted from the shelves of the Rare Books Division in the Library of Congress and published in 41 volumes as The American slave. A composite autobiography (1972-1979). In the United Kingdom, labour historians David Vincent, John Burnett and David Mayall searched local archives and family attics to unearth working-class memoirs from the period 1790-1945, all of which were listed in the annotated bibliography The autobiography of the working class (1984). The Dutch historian Rudolf Dekker even initiated a search through all national, regional and local archives and libraries to list all published and unpublished 'egodocuments' written by Dutch people since 1500 (Lindeman, Scherf\&Dekker). ${ }^{2}$

Feminist historians played a major role in the search for, and dissemination of, historical first-person narratives. Sharing personal experiences and narratives was of course central to the second feminist wave, because the sharing of personal experiences was thought the key to feminist consciousness-raising and the transformation of so-called personal problems into collective, political themes. Combined with the purpose to give women back their history, first-person narratives were considered of extreme relevance to study and write 'herstory' too. In the 1970s and 80s feminist presses, like Virago in the United Kingdom, Frauenoffensive in West-Germany and Sara in the Netherlands, therefore issued 'historical series' which made past women's lives and experiences accessible through reprints of texts such as the diaries of Jewish business woman Glückel von Hameln (1646-1724), Histoire de ma vie (1855) by French writer George Sand and the autobiographical novel Daughter of the earth (1929) by American journalist Agnes Smedley. In 1981, moreover, the International Archive for the Women's Movement (IAV, now: Atria) launched a search project for unpublished 'egodocuments'- diaries, letters, memoirs - written by women. The quest's results were included in the IAV's archival collection, while excerpts of some documents were published in a book that narrated women's history from the perspective of girl's and 
women's life experiences between 1896 and 1979 (Bosch\&Kloosterman; Bosch, 1987; Mevis). A few years later in Austria, feminist historians' search for materials to be included in the exhibition 'Wer wählt, gewinnt? 70 Jahre Frauenwahlrecht' (1989) resulted in the Sammlung Frauennachlässe (1990) at the Historical Institute of the University of Vienna. Asked whether Soeting sees some link between the women-driven Dutch Diary Archive and these earlier feminist historian's efforts, she answers that the body of volunteers, staff and board members is 'more or less coincidence' though.

Coincidence or not, it is clear that the Dutch Diary Archive is indebted to the new social historical tradition that stimulated the return of the human agent in historiography albeit as member of a collective race, gender or class. In the last quarter of the twentieth century the genre of biography came gradually back into academic fashion, but the politicalhistoriographical tide also prompted large-scale searches for diaries, memoirs and other egodocuments in archives, libraries and people's homes. Findings were listed, added to archival collections and sometimes reprinted. Underneath all this archeological work lay the belief that life narratives could serve as entries into specific information that was now perceived to be historically relevant.

Life narratives, in other words, were listed, collected and reprinted because of their contents and/or the identities of their authors. Towards the end of the twentieth century, however, life writing research tended more towards literary themes like narrative structures and emplotment. Influenced by postmodern language and knowledge philosophies, life narratives were no longer perceived as mirrors or reflections of social realities and identities, but as means to make realities and identities. Consequently, the act of writing - often perceived as an act of agency, self-definition and self-fashioning - was considered just as important as what was written about (Smith\&Watson; Chansky\&Hipschen). It is precisely this elevation of diaries and other first-person narratives into a special species of human writing that seems crucial to understand the rise of diary archives since the mid-1980s, and further analysis will show that stimulating history from below was but one objective of these archives.

\section{People's empowerment}

Even though diary archives justify their existence in terms of people's history they have particular weak links with academic history and archival institutions, as I indicated above. On the other hand, the diary archives excell in public participation and community building. Common people not only donate their documents, but also their money, time and energy. In Pieve Sante Stefano, for instance, local community members read the submitted documents and make annual short-lists of the ten best narratives. Out of these ten, a national jury consisting of 'experienced people' - that is, writers and journalists, politicians, and scholars like historians, sociologists and linguists - selects one that is awarded a prize (ADN). This prize event is embedded in an annual 'festival of autobiography', where authors, readers, and other interested parties - such as colleagues from other diary archives - can meet in the town hall of Pieve Sante Stefano, and admire exhibitions of the most precious manuscripts. In France too, local groups of volunteers read the submitted texts, but the APA volunteers also index the manuscripts. These meta-data are, together with reading reports, stored in an online searchable, descriptive catalogue named 'Garde-Mémoire'. Similar to the Italian approach, 
the APA also organizes special events like Autobiography weekends, Diary days and exhibitions (APA). In Emmendingen, the Deutsches Tagebucharchiv organizes an annual 'Biography day' on June 12, the birthday of Anne Frank (Huitema, p. 26). Most archives also publish fragments from their collection in books, journals or on their websites. Characteristic for the diary archives, however, is that virtually all the work that is done relies on active participation of volunteers from the local communities. Only the Deutsches Tagebucharchiv has a number of paid staff members, thanks to warm relations with the mayor of Emmendingen, local business people, and scholars from the nearby university of Freiburg (Huitema, p. 25).

The characteristic spirit of public participation reflects the diary archives' main purpose, a point that is best captured by the very generous admission policies. As a rule the archives have no content- or author-based criteria for inclusion; everybody is welcome to donate their life writings. This democratic, participatory approach was especially crucial to Saverio Tutino, because he meant the Italian diary archive to become a 'house of memory' in which common people could store their contributions to the 'literature of life' and 'today's human conscience' (ADN). Historical relevance, however defined, was therefore no criterium for inclusion. Having been alive was enough. Consequently, the archive serves not so much as an information or knowledge institute but rather as a monumental means to empower and immortalize common people. As Tutino wrote it: 'All the people, who give their own diaries to the Archives, obtain a new power they had not before. For the first time, they have a new social liberty and the satisfaction of a real and primary need, that is to preserve their identity after their death. All this is possible only with the authors' requests for keeping their diaries in the Archives; money is not required. So, the Archives are partly a "cultural service". Essentially, the Archives must increase the cultural value of each personal writing. Besides, they engage themselves to point out people's dignity in any kind of approach to these documents. Without a written trace, people's memory remains without voice; but, when this trace exists, we must keep and protect it (ADN).' Other diary archives operate in a similar spirit, which, in my view, makes also their existence more understandable as monuments for the 'common (wo)man'.

In practice, the diary archives' democratic admission policies conflict with limited storage space. Since no real-life institute can collect everything, some boundaries have to be drawn. Following the archives' refusal to select on the basis of historical relevance or author's characteristics, the only remaining criterium is genre. But in this respect, the diary archives are broad-minded too. All have a very wide conception of the term 'diary', as shows from the fact that the institutes collect diaries and other first-person narratives such as memoirs and letters. Nonetheless, even a broad conception of diaries has limits. The Deutsches Tagebucharchiv, for instance, excludes document types like 'Gästebücher' and 'Rechnungsoder Haushaltsbücher' as well as fictional life narratives and 'unfreiwillig verfasste Zeitzeugnisse (Verhöre, Personalakten)' (DT, Über uns). The Dutch Diary Archive still struggles to find the limits of the diary-concept, as Soeting explains: 'I take the word 'diary' in a very broad sense, and would love to include all sorts of other documents which depict life stories, like medical reports. In fact, this is what we do, though only when it is part of a collection. This means that one 'diary' collection may contain one or several diaries, notes, scrapbooks, medial records as well as photo albums. We would also like to accept objects, 
like the suitcases or satchels in which these documents were kept, but unfortunately the Meertens Institute, which not only houses but also owns the collection (the Dutch Diary Archive takes care of the acquisition and the indexing of the documents), has strict rules against storing objects. And then again, as there is little room in the Institute, we are obliged to reject 'single', no-diary collections, which consist of minutes or photo albums only. If I would have a say in this, I would accept everything that people have decided to keep because they thought of it as a reflection of their lives and lifestyle.' Considering this broad approach, one cannot but wonder about the use of the term 'diary' in the Dutch Diary Archive's name. Soeting answers that the concept is used for mere convenience: 'We wanted to stay in tune, as it were, with the other European archives and collections which are basically all called 'diary archives' or 'diary collections'. Moreover, the word 'diary' is recognizable for nonacademics, who often do not relate to terms like 'egodocuments' or 'life writing'.'

Whatever their democratic approach of diaries and archives, in one respect the European diary collections are surprisingly strict: nationality. Notwithstanding the recent formation of the network of European Diary Archives and Collections (EDAC, 2015), which aims at a collective database to facilitate comparative research, every archive claims to represent the voice of their respective nation's common people. Still, the Dutch Diary Archive is flexible in this respect too. Soeting tells that 'we define 'Dutch' as written in the Dutch language, or written by people who were born in the Netherlands, or have acquired the Dutch nationality, or feel 'Dutch'. The collection thus contains a diary written in German by a man who moved from the Netherlands to Germany in the fifties of the previous century, and the memoirs of a woman who was born as a man in Hungary, which have been written in Dutch.'

To what extent the diary archives live up to their representational goals is hard to assess. Facts and figures on the German diary archive's website show, however, that the collection's bulk stems from authors who live(d) in Baden-Württemberg, the Bundesland in which the Deutsches Tagebucharchiv is located (DT, Fakten und Zahlen). Perhaps the national names and claims must not be understood as reflections of the present collections, but as indications of future ambitions. In this respect, it is revealing that the French association's name has included the concept of 'patrimoine' - heritage, more precisely: national heritage. Once again, this phrase indicates that the collection of common people's lives is much more than just a project to recover historical documents. Diary archives appear to fulfill an almost existential need: to save the common man and woman from oblivion through the elevation of their life narratives into national heritage and memory.

\section{Gender and the autobiographical practice}

Heritage and history are often defined as opposites. As David Lowenthal (1996) most famously stated, 'heritage' is a semi-religious tool for collective identity and memory formation, whereas history is meant to be a scientific, rational discipline. The diary archives don't see such a dichotomy, and combine both concepts: they claim to collect common people's heritage in order to stimulate historical and/or social scientific research into common people's lives. This combination is most visible on the site of the Deutches Tagebucharchiv. Explicit references to the German historiographical tradition of Alltagsgeschichte indicate that 'autobiographische Zeugnisse' must be regarded as sources for socio-historical studies into topics ranging from daily life during World War II to migration experiences of Polish workers 
in the Ruhrgebiet, meat consumption in the 19th and 20th centuries, and themes related to gender history and history of the body: sexuality, fashion, illness and disability, for instance (DT, Recherchethemen). Following the lead of co-founder Lejeune, the APA suggests a rather different research theme: 'the autobiographical impulse', that is the history and sociology of autobiographical writing as such (APA). Why do people write about themselves, how do and did they do it, and what causes possible changes? Taking such a perspective on life writing, the French are especially interested in all aspects related to the practice of autobiographical writing - including the material aspects of donated items.

When asked about a possible connection between the practice of writing diaries and gender, Soeting replies that this is a recurrent theme in interviews: 'Since the founding of the Dutch Diary Archive we have been interviewed by several national newspapers and by national television, and more often than not we have been asked if women write more diaries than men do. The answer is: no, not that we are aware of. But even though we have a good mix of diaries written by men and women, apparently many people think of diary writing as something feminine, which seems to mean 'sentimental', or 'emotional', maybe even 'secretive'.' As to the contents of the collected documents, Soeting adds that these are 'as diverse as any one can imagine: they differ from daily listings of the weather to minutely kept records of what somebody has done and not done from day to day.' But she sees definitely possibilities for gender studies: 'The diaries give insight in the education of girls and boys and the different job opportunities; they give insight in the relations between girls and boys and men and women (one adolescent male writes in the sixties about his girlfriend whom he judges to be 'ill in the head' and who is then sent to see a doctor and given some kind of medication - I suspect the girl was merely protesting against her boyfriend's possesiveness), and they are very interesting in the 'gendered' language which is used, as in the case of the girl who was deemed to be 'ill in the head'. Gendered self presentation and self fashioning can also be gleaned from the diaries.'

Soeting's personal favourites are diaries written by adolescents. 'What strikes me most is that the diaries usually tend to confront the reader with her or his own prejudices and biases: the diaries written by adolescents can be very witty and open, and not at all the tormented jottings one would expect. We are preparing a book on 'puberdagboeken', to be published early 2017.' Soeting is also fascinated by 'diaries which have been glued together or which were or were not meant to be burned.' Such diaries indicate 'that diaries, though they seem to be written for the self, or an older self alone, are always written with another reader in mind, even when the owner of a diary has stated that the diaries must be destroyed after her or his death. Some time ago we received a box full of diaries with the note 'ongelezen verbranden' (burn unread) attached to it. But why didn't the writer burn the diaries himself? Did he hope somebody would ignore his wishes, as they did? We also received a couple of diaries which have their pages glued together, because the writer decided they belonged to a different life - a life she had shared with a woman, before she fell in love with a man. So why didn't she destroy them?' Perhaps an answer lies in what Soeting said earlier about the motives of people to submit their documents to the Dutch Diary Archive: 'most people bring the diaries for safekeeping: they hate the idea that the diaries might be thrown away by a careless family member, or just get lost.' In this sense, the rise of diary archive may be a new development in the practice of autobiographical writing. Diary archives might suit a 
historical or sociological interest in the lives of common people, but they appear first and foremost to satisfy some contemporary need to find a home for the self, even or especially after death.

Marijke Huisman (1972) is assistant professor Public History at the Department of History and Art History, Utrecht University, the Netherlands. Website: marijkehuisman.com. E-mail: m.h.huisman@uu.nl.

\section{Literature}

Archivio Diaristico Nazionale. (ADN) Saverio Tutino. The archives of Pieve Sante Stefano. Retrieved from: http://archiviodiari.org/index.php/larchivio-dei-diari/421.html.

Assocation pour l'autobiographie et le patrimoine autobiographique. (APA) The APA in a few words. Retrieved from: http://autobiographie.sitapa.org/informations-pratiques/langues-etrangeres/article/english.

Booth, A. (2004). How to make it as a woman. Collective biographical history from Victoria from the present. Chicago: University of Chicago Press.

Bosch, M. (2005). Een onwrikbaar geloof in rechtvaardigheid. Aletta Jacobs, 1854-1929. Amsterdam: Balans.

Bosch, M. \& Kloosterman, A. (1983). In aardappelkistjes en wijndozen. De verzameling ongepubliceerde egodocumenten van vrouwen in het IAV. Lover 10:4, 259-266.

Bosch, M. (1987). A woman’s life in a soapbox. History Workshop Journal 4:24, 166-170.

Botkin, B.A. (1989 [1945]). Lay my burden down. A folk history of slavery. Athens: University of Georgia Press.

Chansky, R.A. \& Hipchen, E. (Eds.) (2016). The Routledge auto|biography studies reader. London: Routledge.

Dekker, R. (2002). Jacques Presser’s heritage. Egodocuments in the study of history. Memoria y Civilización 5, 13-27.

Deutsches Tagebucharchiv. (DT) Über uns. Retrieved from: http://tagebucharchiv.de/tagebucharchiv/ueber-uns/. Deutsches Tagebucharchiv. (DT) Fakten und Zahlen. Retrieved from: http://tagebucharchiv.de/faktenzahlen/. Deutsches Tagebucharchiv. (DT) Rescherchethemen. Retrieved from: http://tagebucharchiv.de/recherche/recherchethemen/.

Frauennächlasse Sammlung. Über uns. Retrieved from: http://www.univie.ac.at/Geschichte/sfn/index.php?option=com_content\&view=article\&id=2\&Itemid=2\&lang=e n.

Hirsch, J. (2003). Portraits of America. A cultural history of the Federal Writers' Project. Chapel Hill: University of North Carolina Press.

Huisman, M. (2011). Autobiography and contemporary history. The Dutch reception of autobiographies, 18501918. In: A. Baggerman, R. Dekker \& M. Mascuch (Eds.). Controlling time and shaping the self. Developments in autobiographical writing since the sixteenth century (387-341). Leiden/Boston: Brill.

Huisman, M. (2015). Life writing in the Netherlands. European Journal of Life Writing 4, R19-R26, http://ejlw.eu/article/view/171/323.

Huitema, C. (2013). Zorgen voor stille getuigen. De missie van het Nederlands Dagboekarchief. Genealogie 19, 24-27.

Lejeune, P. (1975). Le pacte autobiographique. Paris: Seuill. English translation in: Eakin, P.J. (Ed.), (1989). On autobiography (3-30). Minneapolis: University of Minnesota Press. 
Lindeman, R., Scherf, Y. \& Dekker, R. (1993). Egodocumenten van Noord-Nederlanders van de zestiende tot begin negentiende eeuw. Een chronologische lijst. Rotterdam: Erasmus Universiteit.

Lowenthal, D. (1996). Possessed by the past: the heritage crusade and the spoils of history. New York: The Free Press.

Mevis, A. (Ed.) (1985). In verloren minuten. Dagboeken en herinneringen van vrouwen, 1896-1979. Weesp: Fibula-Van Dishoeck.

Nederlands Dagboekarchief. (ND) Waarom dit archief? Retrieved from: http://www.dagboekarchief.nl/waaromeen-dagboekarchief.

Popkin, J.D. (2005). History, historians, \& autobiography. Chicago: University of Chicago Press,

Popkin, J,D. \& Rak J. (Eds.). (2009). Philippe Lejeune. On diary. Manoa: University of Hawai’i Press.

Ranke, L. von (1885 [1824]). Geschichten der romanischen und germanischen Völker von 1494 bis 1514. Zur Kritik neuerer Geschichtschreiber. Dritte Auflage. Leipzig: Verlag von Duncker und Humblot.

Rawick, George P. (Ed.). (1972-1979). The American slave. A composite autobiography. Westport: Greenwood Publishing Company.

Smith, S. \& Watson, J. (2001). Reading autobiography. A guide for interpreting life narratives (Chapter 6: A history of autobiography criticism, part 2: contemporary theorizing). Minneapolis: University of Minnesota Press.

Vincent, D.,Burnett, J. \& Mayall, D. (1984) The autobiography of the working class. New York: New York University Press.

Walser, G. (2016, Interview mit Frauke von Troschke, Gründerin des Deutschen Tagebucharchives. Badische Zeitung, 2 April. Retrieved from: http://www.badische-zeitung.de/emmendingen/interview-mit-frauke-vontroschke-gruenderin-des-deutschen-tagebucharchivs--120232267.html.

Yetman, N.R. (1967). The background of the Slave Narrative Collection. American Quarterly 19:3, 534-553.

\footnotetext{
${ }^{1}$ Lejeune's claim to fame is his notion of the 'autobiographical pact' (1975). Over time his research interest has shifted towards diaries. Lejeune's work on diaries has been made available in English through Popkin \& Rak (2009).

${ }^{2}$ This, and subsequent inventories that cover (un)published egodocuments of the 19th and 20th centuries can be accessed through the website www.egodocument.net.
} 